Provided for non-commercial research and education use. Not for reproduction, distribution or commercial use.

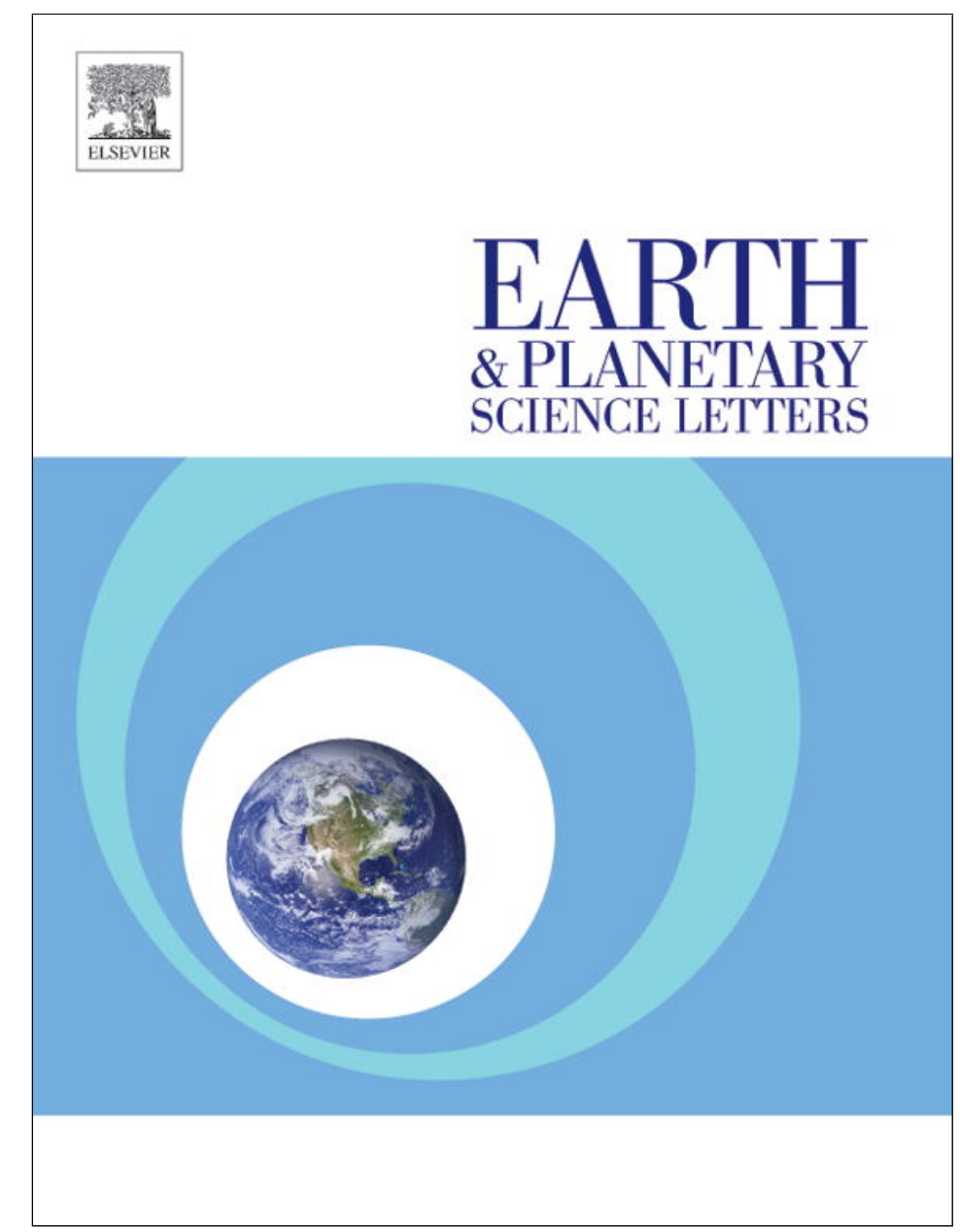

(This is a sample cover image for this issue. The actual cover is not yet available at this time.)

This article appeared in a journal published by Elsevier. The attached copy is furnished to the author for internal non-commercial research and education use, including for instruction at the authors institution and sharing with colleagues.

Other uses, including reproduction and distribution, or selling or licensing copies, or posting to personal, institutional or third party websites are prohibited.

In most cases authors are permitted to post their version of the article (e.g. in Word or Tex form) to their personal website or institutional repository. Authors requiring further information regarding Elsevier's archiving and manuscript policies are encouraged to visit:

http://www.elsevier.com/copyright 


\title{
Passive vs. active degassing modes at an open-vent volcano (Stromboli, Italy)
}

\author{
G. Tamburello ${ }^{\text {a,* }}$, A. Aiuppa ${ }^{\text {a,b }}$, E.P. Kantzas ${ }^{\text {c }}$, A.J.S. McGonigle ${ }^{\text {b,c }}$, M. Ripepe ${ }^{\mathrm{d}}$ \\ a Dipartimento DiSTeM, Università di Palermo, via Archirafi 36, 90123 Palermo, Italy \\ ${ }^{\mathrm{b}}$ Istituto Nazionale di Geofisica e Vulcanologia, Sezione di Palermo, Italy \\ ${ }^{\mathrm{c}}$ Department of Geography, University of Sheffield, UK \\ ${ }^{\mathrm{d}}$ Dipartimento Scienze della Terra, Università di Firenze, Italy
}

\section{A R T I C L E I N F O}

\section{Article history:}

Received 14 December 2011

Received in revised form

24 September 2012

Accepted 27 September 2012

Editor: T. Elliot

\section{Keywords:}

volcanic degassing

Strombolian explosions

puffing

UV camera

high time resolution $\mathrm{SO}_{2}$ flux

\begin{abstract}
A B S T R A C T
We report here on a UV-camera based field experiment performed on Stromboli volcano during 7 days in 2010 and 2011, aimed at obtaining the very first simultaneous assessment of all the different forms (passive and active) of $\mathrm{SO}_{2}$ release from an open-vent volcano. Using the unprecedented spatial and temporal resolution of the UV camera, we obtained a $0.8 \mathrm{~Hz}$ record of the total $\mathrm{SO}_{2}$ flux from Stromboli over a timeframe of $\sim 14 \mathrm{~h}$, which ranged between 0.4 and $1.9 \mathrm{~kg} \mathrm{~s}^{-1}$ around a mean value of $0.7 \mathrm{~kg} \mathrm{~s}^{-1}$ and we concurrently derived $\mathrm{SO}_{2}$ masses for more than 130 Strombolian explosions and 50 gas puffs. From this, we show erupted $\mathrm{SO}_{2}$ masses have a variability of up to one order of magnitude, and range between 2 and $55 \mathrm{~kg}$ (average $\sim 20 \mathrm{~kg}$ ), corresponding to a time integrated flux of $0.05 \pm 0.01 \mathrm{~kg} \mathrm{~s}{ }^{-1}$. Our experimental constraints on individual gas puff mass $(0.03-0.42 \mathrm{~kg}$ of SO , averaging $0.19 \mathrm{~kg}) \mathrm{are}$ the first of their kind, equating to an emission rate ranging from 0.02 to $0.27 \mathrm{~kg} \mathrm{~s}^{-1}$. On this basis, we conclude that puffing is two times more efficient than Strombolian explosions in the magmatic degassing process, and that active degassing (explosions + puffing) accounts for 23\% (ranging from $10 \%$ to $45 \%$ ) of the volcano's total $\mathrm{SO}_{2}$ flux, e.g., passive degassing between the explosions contributes the majority $(\sim 77 \%)$ of the released gas. We furthermore integrate our UV camera gas data for the explosions and puffs, with independent geophysical data (infrared radiometer data and very long period seismicity), to offer key and novel insights into the degassing dynamics within the shallow conduit systems of this open-vent volcano.
\end{abstract}

(c) 2012 Elsevier B.V. All rights reserved.

\section{Introduction}

Active volcanoes dissipate their magma-transported energy in a variety of ways, among which volcanic degassing is often dominant (Oppenheimer, 2003). Passive degassing is frequently the only visible surface expression of the activity of quiescent volcanoes, and also makes up a large fraction of the daily mass/ energy release from persistent basaltic volcanoes (Shinohara, 2008). At such open-vent systems, this passive degassing frequently coexists with active degassing forms, resulting from emission of over-pressurised gas jets/pockets in either explosions or puffs (Harris and Ripepe, 2007). Puffing, in particular, is a typical degassing mode of Stromboli and consists of the emission of small overpressurised gas pockets. Near-surface gas bursting is the trigger for mildly explosive activity at basaltic volcanoes (Parfitt, 2004), and whilst this is thought to represent only a small part of the total degassing budget of a volcano (Allard et al., 1994), measurements of this phenomenon provide important

\footnotetext{
* Corresponding author. Tel.: +3909123861618.

E-mail address: giancarlotamburello@gmail.com (G. Tamburello).
}

information regarding explosion triggering mechanisms, and therefore on the volcanic behaviour in general (e.g., Allard et al., 2004; Burton et al., 2007a).

Over the last few decades, remote sensing techniques working in the UV region of the electromagnetic spectrum have increasingly been applied to explore the long-term (years) to mediumterm (days) trends in the rate of $\mathrm{SO}_{2}$ release from active subaerial volcanoes (McGonigle and Oppenheimer, 2003; Oppenheimer et al., 2011; Tamburello et al., 2011a). From these observations, the time-averaged budgets of $\mathrm{SO}_{2}$ release for a number of individual volcanoes have been obtained, leading to assessments of the global volcanic $\mathrm{SO}_{2}$ flux (Andres and Kasgnoc, 1998). In spite of this progress, however, the relative contributions of passive and active degassing within the overall gas budget of volcanoes remain largely unconstrained. This comes from the fact that active degassing processes, such as gas release during Strombolian explosions or gas puffing, typically correspond to timescales of seconds, therefore cannot be resolved with traditional (scanning or traverse) techniques, which generally have a temporal resolution of tens of minutes.

The recent advent of the UV camera represents a step forward in volcanic gas remote sensing (Mori and Burton, 2006; Bluth 
et al., 2007), allowing $\mathrm{SO}_{2}$ measurement to be carried out with unprecedented spatial and temporal resolution. This technique has rapidly found widespread usage in targeting previously

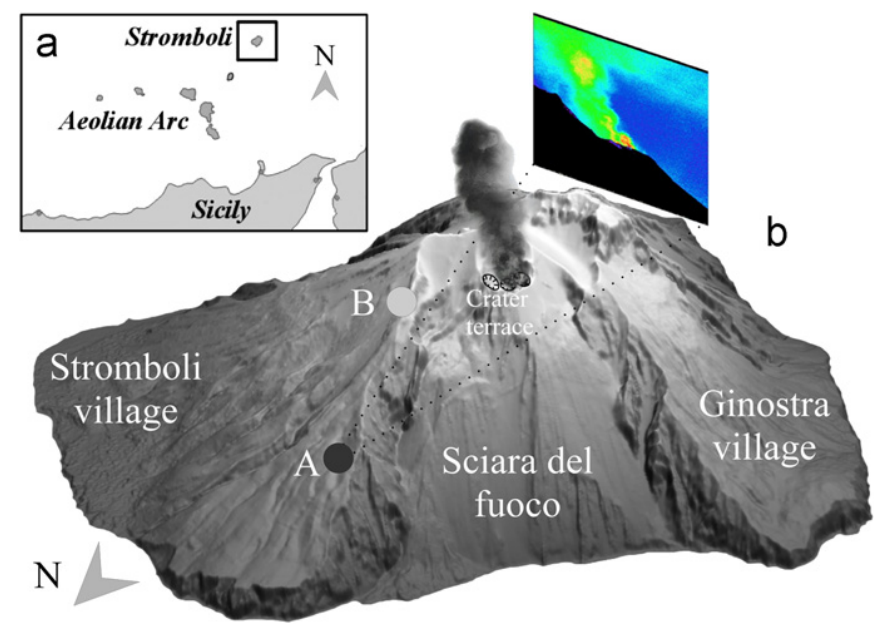

Fig. 1. (a) Location of Stromboli with respect to Sicily, (b) digital elevation model of Stromboli (courtesy of M. Marsella), showing locations of the measurement sites: A, SAR observation site (dark grey circle); B, Roccette site (light gray circle); see the. $\mathrm{kml}$ file in the auxiliary material. A sample graphical representation of gas concentrations in the UV camera field of view from site A is shown in the pseudocolour image (the $\mathrm{SO}_{2}$-rich gas plume is in green). unresolvable volcanic degassing phenomena, such as the $\mathrm{SO}_{2}$ budgets of individual strombolian (Mori et al., 2009; Dalton et al., 2009) and vulcanian (Holland et al., 2011; Nadeau et al., 2011) explosions, and spatial analysis of heterogeneous gas sources such as fumarolic systems (Tamburello et al., 2011b).

Here, we use the dual-UV camera technique detailed in Kantzas et al. (2010) and Tamburello et al. (2011b) to provide a comprehensive and simultaneous characterization of the three main forms of $\mathrm{SO}_{2}$ gas release from Stromboli volcano: passive degassing, explosive degassing, and puffing. Stromboli, in the Aeolian islands (Fig. 1), is the archetype for "strombolian" activity, an eruptive behaviour found on many other volcanoes. On Stromboli, explosions are regularly super-imposed on top of the persistent quiescent degassing activity, with each event lasting a few seconds at most (mean duration, $15 \mathrm{~s}$; Patrick et al., 2007), and 300 explosions/day (Ripepe et al., 2008). Syn-explosive gas emissions therefore have a cumulative duration of only $\sim 80 \mathrm{~min}$ per day, which led Allard et al. (1994) to suggest that their contribution to the total daily $\mathrm{SO}_{2}$ budget $\left(250 \pm 50 \mathrm{t} \mathrm{d}^{-1}\right.$; Allard et al., 2008) is relatively low. The few previous measurements (a total of only $\sim 30$ explosions have been characterised to date; Allard et al., 1994; Mori et al., 2009; McGonigle et al., 2009) also tentatively indicate that explosions may correspond to only $3-8 \%$ of the total $\mathrm{SO}_{2}$ flux. In addition to explosions, Stromboli is also the site of persistent and repetitive (every 1-2 s) release of small overpressurised gas pockets during puffing (Harris and Ripepe, 2007). While no direct measurements

Table 1

Location, timing and technical informations of the measured total $\mathrm{SO}_{2}$ flux from Stromboli.

\begin{tabular}{|c|c|c|c|c|c|c|c|}
\hline Date & $\begin{array}{l}\text { Start } \\
\text { (local } \\
\text { time) } \\
\text { (h:min) }\end{array}$ & $\begin{array}{l}\text { Duration of } \\
\text { timeseries } \\
\text { (h) }\end{array}$ & $\begin{array}{l}\text { Plume } \\
\text { speed } \\
\left(\mathrm{m} \mathrm{s}^{-1}\right)\end{array}$ & $\begin{array}{l}\mathrm{SO}_{2} \text { flux } \\
\text { mean } \\
\text { st. dev. } \\
\text { min } \\
\text { max quiescient } \\
(\max \text { explosive) } \\
\left(\mathrm{kg} \mathrm{s}^{-1}\right)\end{array}$ & Site & $\begin{array}{l}\text { Number of } \\
\text { strombolian } \\
\text { explosions }\end{array}$ & Note \\
\hline $\begin{array}{l}10 \text { July, } \\
2010\end{array}$ & 10:05 & 2.5 & 2.6 & $\begin{array}{l}\mathbf{0 . 6} \\
0.15 \\
0.3 \\
0.95 \\
(1.1)\end{array}$ & SAR & 37 & \\
\hline $\begin{array}{l}11 \text { July, } \\
2010\end{array}$ & 09:26 & 2.2 & 2.4 & $\begin{array}{l}\mathbf{0 . 8 1} \\
0.17 \\
0.5 \\
0.9 \\
(3.2)\end{array}$ & SAR & 35 & \\
\hline $\begin{array}{l}12 \text { July, } \\
2010\end{array}$ & 10:02 & 3 & 2.5 & $\begin{array}{l}\text { n.d. } \\
\text { n.d. } \\
\text { n.d. } \\
\text { n.d. } \\
(0.6)\end{array}$ & SAR & 32 & $\begin{array}{l}\text { Strong wind, plume grounded and partially } \\
\text { hidden behind the craters. }\end{array}$ \\
\hline $\begin{array}{l}13 \text { July, } \\
2010\end{array}$ & $14: 13$ & 2.3 & 2.2 & $\begin{array}{l}\text { n.d. } \\
\text { n.d. } \\
\text { n.d. } \\
\text { n.d. } \\
(0.7)\end{array}$ & SAR & 17 & $\begin{array}{l}\text { Strong wind, plume grounded and partially } \\
\text { hidden behind the craters. }\end{array}$ \\
\hline $\begin{array}{l}14 \text { July, } \\
2010\end{array}$ & $13: 50$ & 3 & n.d. & n.d. & SAR & 26 & $\begin{array}{l}\text { Strong wind and wrong direction, plume grounded } \\
\text { and totally hidden behind the craters. Only the explosions } \\
\text { visible. }\end{array}$ \\
\hline $\begin{array}{l}16 \text { July, } \\
2010\end{array}$ & 09:58 & 1 & 3.4 & $\begin{array}{l}\mathbf{1 . 9} \\
0.3 \\
0.5 \\
2.4 \\
(3.7)\end{array}$ & Roccette & n.d. & Too close to be able to measure the explosions. \\
\hline
\end{tabular}


of the gas flux contributed by puffing has been reported to date, thermal data have been used to argue that puffing could be the major expression of explosive degassing on Stromboli, involving release of up to $\sim 100 \mathrm{td}^{-1} \mathrm{SO}_{2}$ (or up to $45 \%$ of the total degassing budget) (Harris and Ripepe, 2007; Ripepe et al., 2008).

The aim of this paper is to better quantify and budget the different form of degassing on Stromboli volcano, and to intercompare these data with contemporaneous geophysical signals. These results have implications not only for the understanding of degassing mechanisms on Stromboli, but also at other open-vent basaltic volcanoes, worldwide.

\section{Hardware and technique}

We report here on results of a UV camera survey carried out on Stromboli from the 10th to the 16th of July 2010. Additional data collected on the 20th May 2011 are also included. Overall, we recorded $\sim 10 \mathrm{~h}$ of imagery, and observed 133 explosions and $\sim 60$ puffs throughout. Most measurements were carried out from the SAR site, on the northern rim of the Sciara del Fuoco (Fig. 1), $\sim 1 \mathrm{~km}$ from the volcano's summit and full details on the locations and timings of the acquisition are provided in Table 1 . Considering the close proximity of this site, any error or artefact related to distance from the target (Bluth et al., 2007; Kern et al., 2009) had likely only very minimal impacts upon our measurements.

\subsection{Instrumental setup}

Over the last few years, UV cameras have been developed for imaging $\mathrm{SO}_{2}$ emissions from volcanoes. They have been deployed in a number of different configurations: a single camera with a filter (Bluth et al., 2007; Mori and Burton, 2009; Yamamoto et al., 2008); one camera with two switching filters (Mori and Burton, 2006); and lastly, two cameras with a filter each (Kantzas et al., 2010). The latter configuration was used for this work, providing the highest possible time resolution, and the ability to manage errors arising from broadband absorption e.g., aerosols and ash. The instrumentation consisted of two Apogee Instruments Alta U260 cameras, each fitted with a 16 bit $512 \times 512$ pixel Kodak KAF-0261E thermo-electrically cooled CCD array detector, and powered with a $12 \mathrm{~V}$ battery. A steel rail mounted over a tripod ensured that the cameras had quasi-identical fields of view, and following acquisition, the camera images were shifted relative to one another in software, to perfect their alignment.. The UV lenses mounted to the fore of the cameras were Pentax B2528-UV units of $f=25 \mathrm{~mm}$ providing a field of view (FOV) of $\sim 24^{\circ}$. Filters were placed over each of these lenses: of $10 \mathrm{~nm}$ FWHM (Asahi bunko Inc.) and centred on $310 \mathrm{~nm}$ (affected by plume $\mathrm{SO}_{2}$ absorption) and $330 \mathrm{~nm}$ (where $\mathrm{SO}_{2}$ does not absorb), respectively. This system provided sufficient spatial resolution, $(\sim 1.2 \mathrm{~m})$, when measuring $\sim 1 \mathrm{~km}$ from the plume, to distinguish between explosions from the central craters (central and SW) and from the NE crater (Fig. 1). Calibration was achieved with quartz cells containing known column amounts of $\mathrm{SO}_{2}$, placed in front of the lenses, every half an hour during the measurements. The UV cameras were controlled by a freely downloadable user-friendly code (Vulcamera; Tamburello et al., 2011c), which manages both image acquisition, and all elements of post-processing; for further comprehensive detail on the acquisition, processing and calibration steps please see Kantzas et al. (2010).

\section{2. $\mathrm{SO}_{2}$ flux calculations}

Traditionally, UV scanning and traversing techniques have been used to derive $\mathrm{SO}_{2}$ column amount profiles e.g., $C(x)$ through one cross section of the plume. By converting concentrations from ppm $\mathrm{m}$ to $\mathrm{kg} \mathrm{m}^{-2}$, and subsequently integrating $C(x)$ from the start point $x_{i}$ to the end $x_{f}$ of the plume, the integrated column amount $\left(I C A ; \mathrm{kg} \mathrm{m}^{-1}\right)$ can be obtained, as

$$
\text { ICA }\left(\mathrm{kg} \mathrm{m}^{-1}\right)=\int_{x_{i}}^{x_{f}} C d x
$$

This is then multiplied by plume transport speed $\left(\mathrm{m} \mathrm{s}^{-1}\right)$ to compute $\mathrm{SO}_{2}$ flux $\left(\mathrm{kg} \mathrm{s}^{-1}\right)$.

In order to derive accurate and high-frequency $(\sim 1 \mathrm{~Hz}) \mathrm{SO}_{2}$ flux time series with the UV cameras, we first considered a cross section through the rising plume (first cross section in Fig. 2a) a few metres above the vents, for which we obtained $\mathrm{SO}_{2}$ concentration profiles, over the pixels, e.g., that shown in Fig. $2 \mathrm{~b}$, and, by integration, the ICA. Then, in order to calculate the plume transport speed, we calculated ICA time series for this cross section, and a second, parallel to the first and elevated by a distance: $\Delta X$ (Fig. 2a). These series were separated by a time shift $\Delta T$, corresponding to the time for a cloud of gas to travel from the first to the second section (e.g., as in Fig. 2c) (McGonigle et al., 2009; Boichu et al., 2010). The mean plume speed $V_{m}$ in that
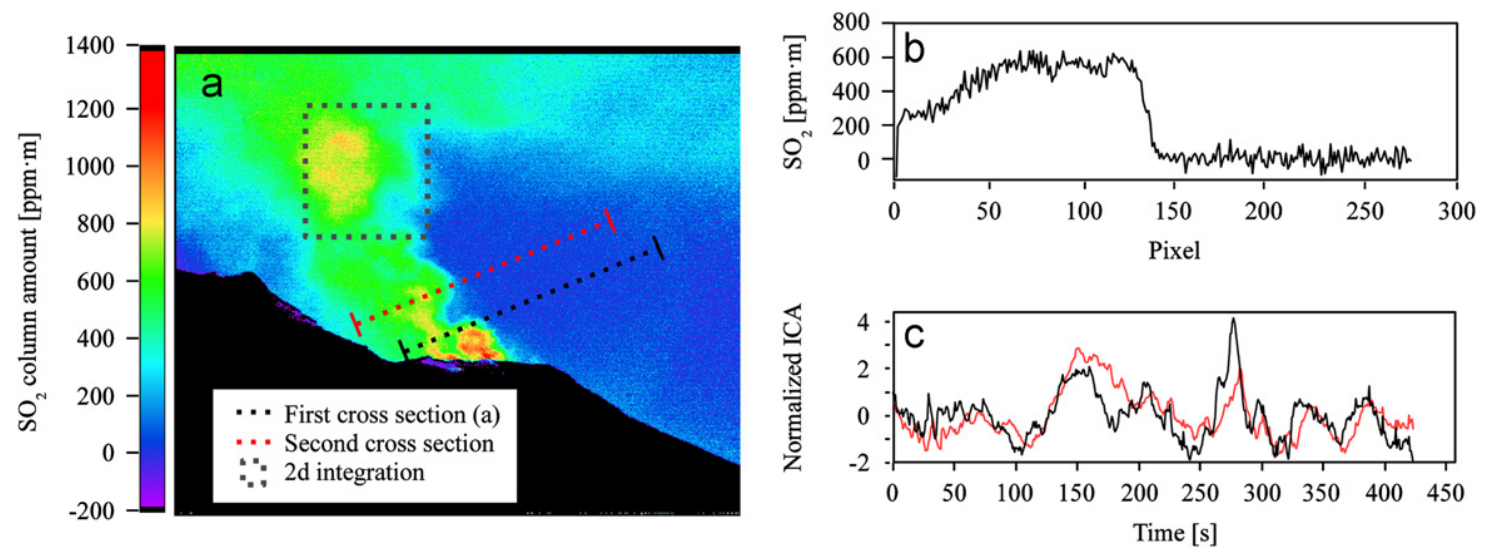

Fig. 2. (a) $\mathrm{SO}_{2}$ column amount image obtained from the $\mathrm{SAR}$ observation site. The black and red dotted lines represent the two sections taken for the $\mathrm{SO}_{2}$ flux and plume speed calculation (see text), the gray dotted square shows an example of an integration area over which the total (cumulative) $\mathrm{SO}_{2}$ amount (in kilograms) is calculated (Section 2.3); (b) Pixel-to-pixel variation of $\mathrm{SO}_{2}$ column amounts along a cross section of the plume (black dotted line in (a)). $\mathrm{SO}_{2}$ is integrated along the profile to obtain the integrated column amount (ICA), then multiplied by the plume speed to derive $\mathrm{SO}_{2}$ flux (c) Normalized ICA time series from the two cross sections of the pseudo-colour graph (black and red dotted line), showing a typical time delay $\Delta T$ between the two series: the plume speed is calculated from $\Delta T$ and then known distance $\Delta X$ between the two sections. 
interval will be:

$V_{m}=\frac{\Delta X}{\Delta T}$

In practice, mean plume speeds were calculated by cross correlating these two ICA time series to find $\Delta T$, for every episode of passive degassing, between the explosions. The explosions themselves are too fast however, to permit measurement of delay $\Delta T$ in this way, therefore a velocity profile has been calculated manually by visually observing the progression of the eruption cloud across the field of view, in an image sequence. This process is expedited by the marked contrast between the high $\mathrm{SO}_{2}$ concentration in the explosive gas plume against the far weaker quiescent plume.

\section{3. $\mathrm{SO}_{2}$ mass from individual explosions and puffing}

UV camera images also provide concentration distribution information in two dimensions $C(x, y)$; by integrating a second time along the dimension perpendicular to that of the integrated column amount plane, one can calculate the integrated volume amount (IVA), e.g., the cumulative amount of $\mathrm{SO}_{2}$ within an imaginary pyramid of infinite thickness (see gray dotted square, for the base of this, in Fig. 2a):

$\operatorname{IVA}(\mathrm{kg})=\int_{x_{i}}^{x_{f}} \int_{y_{i}}^{y_{f}} C d x d y$

This calculation does not require knowledge of the plume speed, thus overcomes the inherent difficulty in measuring the ascent rate of the explosive gas thrust (see above). Hence, two dimensional integration was used here to calculate the $\mathrm{SO}_{2}$ mass from individual explosive bursts (results in Section 2.5), and puffs (Section 2.6). The integration window height and width were chosen in order to contain the entire targeted $\mathrm{SO}_{2}$ cloud and part of the background, ranging between $\sim 160 \times 220$ pixels for the explosions and $\sim 30 \times 30$ pixels for puffs. The former was more or less constant across most events, although slightly bigger windows were required for the largest explosions; in the latter case this pixel range was always used as puff volumes are rather constant.

Some strombolian explosions erupt fine particles which are coupled with the gas phase, creating an ash-rich plume. Ash represents an obstacle to accurate measurement of the erupted $\mathrm{SO}_{2}$ mass, because it prevents sun light from passing through the plume, causing absorption and back reflection at the surface of the cloud (Kern et al., 2009). Ash settles down rapidly from the eruptive plume, however, making it more and more transparent during ascent and dispersion in the atmosphere. A good proxy for the transparency of the explosive plume is the ratio between the mean light intensity recorded by the $330 \mathrm{~nm}$ filter camera inside the cloud $\left(I_{e, 330}\right)$, and the light intensity of the background $\left(I_{b, 330}\right.$ clear sky), the so called ash index $(A I)$, assuming that ash is the main cause of light attenuation:

$A I=\frac{I_{e, 330}}{I_{b, 330}}$

Theoretically, in the absence of ash, the index should be $\sim 1$; in practice, however, the plume contains water vapour and aerosols that also absorb in this range of wavelengths, such that the $A I$ ranges between 0.5 and 0.8 , even for ash-free explosions. Fig. 3 The site is $\sim 1 \mathrm{~km}$ from the crater terrace $(\sim 750 \mathrm{~m}$ asl), and ensured a clear view of the explosions, as shown in Figs. 1 and 2. Additional measurements were taken (on July 16th 2010 and May 20th 2011) at the more proximal site ROC (Fig. 1), from which a clear view of puffing degassing from the central crater was occasionally possible. During the whole campaign, the plume

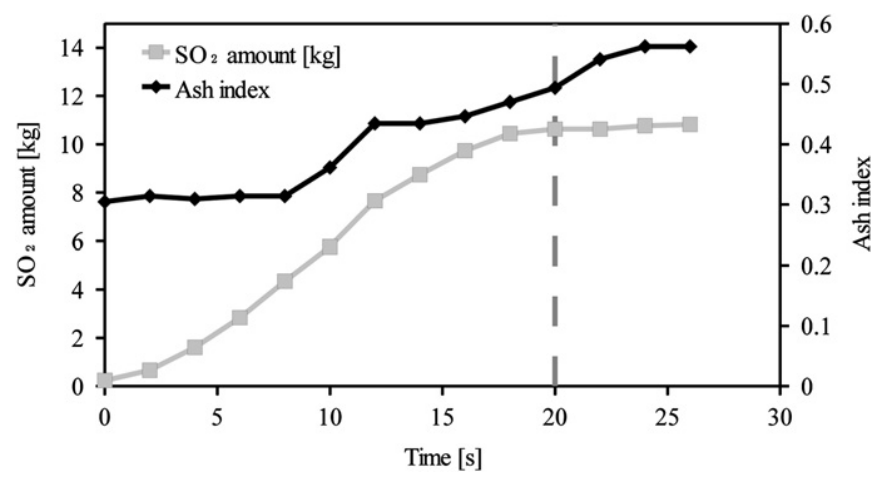

Fig. 3. Time variation of $\mathrm{SO}_{2}$ amount (in $\mathrm{kg}$ ) and ash index during an ash-rich explosion (time 0 - the explosion onset - is fixed from the first appearance of a thermal signal in the radiometer). The timeseries has been evaluated following the explosion from $0 \mathrm{~m}$ up to $\sim 100 \mathrm{~m}$ above the vent. The figure shows that a steady $\mathrm{SO}_{2}$ value (dotted line) is achieved for $A I \geq 0.5$ ( $\sim 20 \mathrm{~s}$ after the explosion onset).
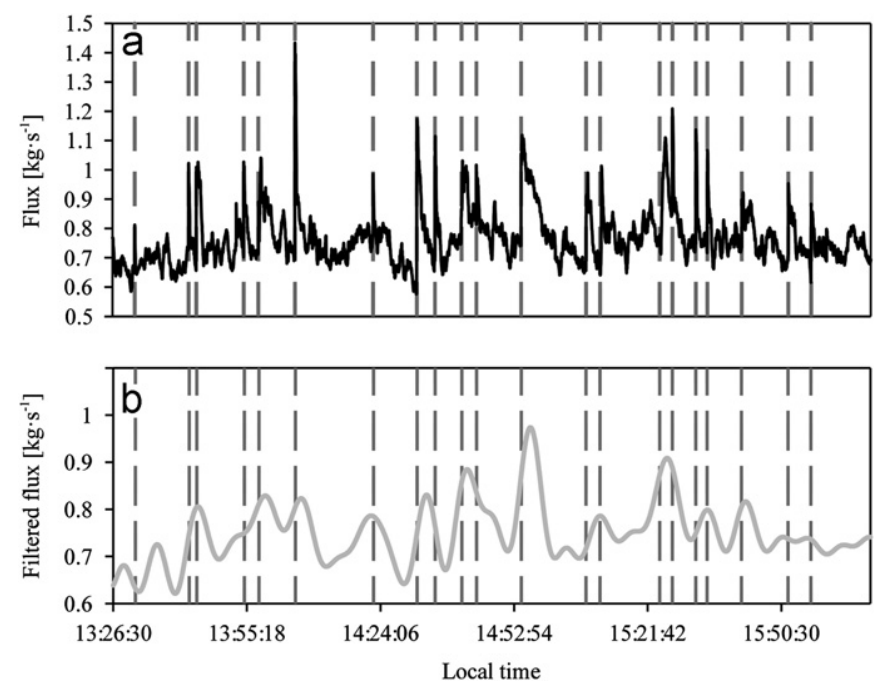

Fig. 4. (a) A 2-h high frequency $(0.8 \mathrm{~Hz})$ record of the total $\mathrm{SO}_{2}$ flux from Stromboli from site A, recorded on July 11 th, 2010. Each explosion (vertical dotted line) is associated with a large $\mathrm{SO}_{2}$ flux increase, followed by a few-minute long decay coda. This, combined with the rhythmic nature of Strombolian explosions, causes "periodic" $\mathrm{SO}_{2}$ degassing behaviour (period, $\sim 300-700 \mathrm{~s}$ ), which is clearly visible in the $0.004 \mathrm{~Hz}$ low-pass filtered $\mathrm{SO}_{2}$ time series in (b).

remained transparent (with very little condensation), and rose quasi-vertically under relatively windless conditions; convection was the dominant transport mechanism for the ascending gas (plume buoyancy $\sim 3 \mathrm{~m} / \mathrm{s}$ ).

\section{Results}

From 10th to 15th of July, we deployed the UV cameras on the lower north rim of the Sciara del Fuoco on Stromboli at the SAR location, about $350 \mathrm{~m}$ asl (Fig. 1). The site is $\sim 1 \mathrm{~km}$ from the crater terrace $(\sim 750 \mathrm{~m}$ asl), and ensured a clear view of the explosions as shown in Figs. 1 and 2. Additional measurements were taken (on July 16th 2010 and May 20th 2011) at the more proximal site ROC (Fig. 1), from which a clear view of puffing degassing from the central crater was occasionally possible. During the whole campaign, the plume remained transparent (with very little condensation), and rose quasi-vertically under relatively windless conditions; convection was the main motion mechanism of the rising gas (plume buoyancy $\sim 3 \mathrm{~m} / \mathrm{s}$ ). 
a
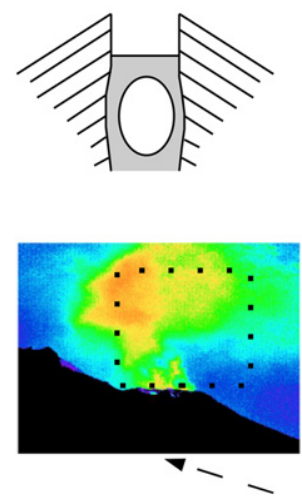

b
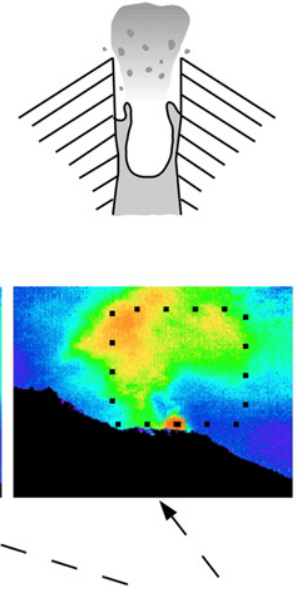

C
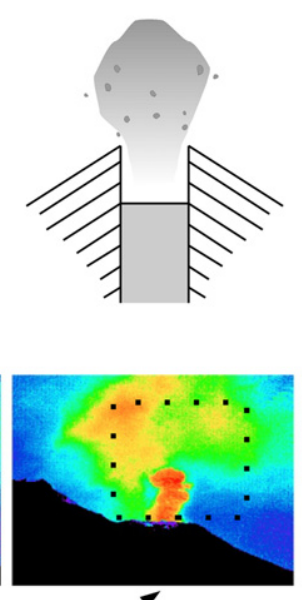

d
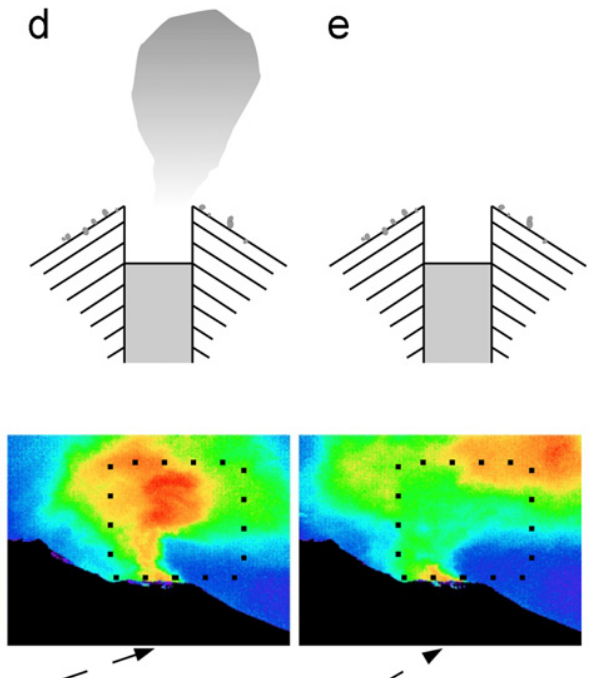

e
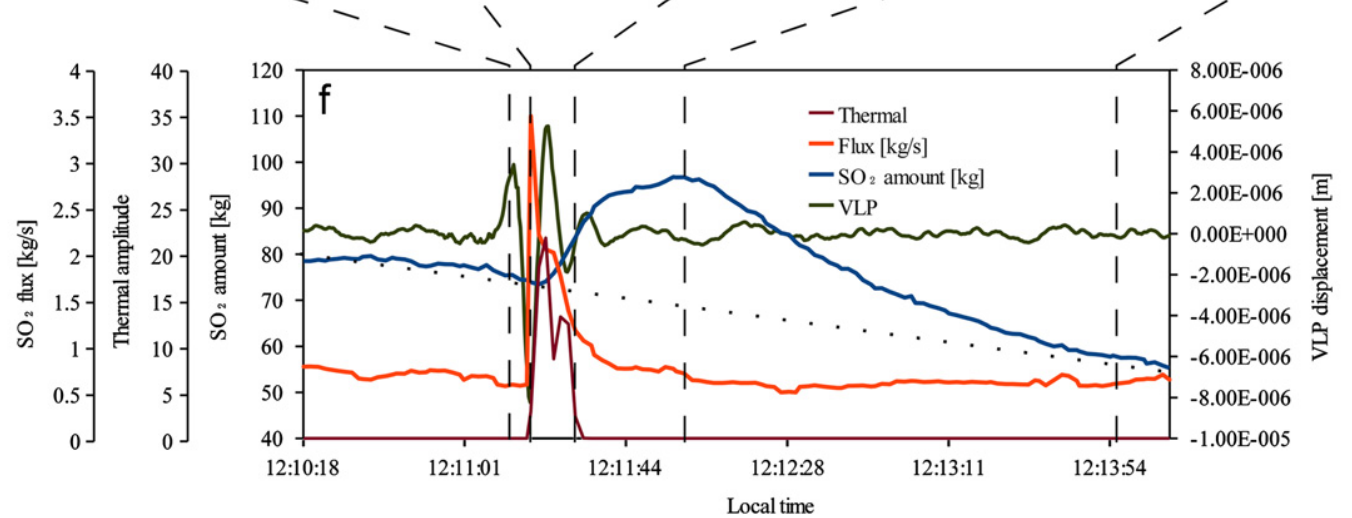

Fig. 5. (a-e) $\mathrm{SO}_{2}$ column amount image sequence (pseudo-colour graphs) taken prior to (a), during (b-d), and after (e) a Strombolian explosion, and schematic illustration of the related conduit processes involved (sketches on the top); (f) inter-comparison between $\mathrm{SO}_{2}$ flux, $\mathrm{SO}_{2}$ amount, VLP displacements and thermal amplitude, all simultaneously recorded before, during and after the explosion (the onset time of which corresponds to frame (b)). Thermal and $\mathrm{SO}_{2}$ flux signals are nearly synchronous, while the $\mathrm{SO}_{2}$ flux trend lags behind onset of the VLP signal. The $\mathrm{SO}_{2}$ amount trace (blue line in (f)) is obtained by applying the two dimension integration technique (Section 2.3) to the area delimited by the dotted box of frames (a) to (e). The $\mathrm{SO}_{2}$ mass (in $\mathrm{kg}$ ) released by the explosion is calculated by subtracting the background (black dotted line in (f)) from the maximum (frame d) of the $\mathrm{SO}_{2}$ amount curve (blue line).

\subsection{Total $\mathrm{SO}_{2}$ flux}

The two PC-synchronised cameras captured (at $\sim 0.8 \mathrm{~Hz}$ rate) sequential images of the bulk (active and passive degassing) craters' plume (Fig. 2a), from which we derived high timeresolution time series of the $\mathrm{SO}_{2}$ flux, an example of which is given in Fig. 4.

For each acquisition day, we averaged the large number of $\mathrm{SO}_{2}$ flux measurements taken to obtain robust evaluations of total $\mathrm{SO}_{2}$ flux emissions, as summarised in Table 1 . According to our data, Stromboli's daily time average $\mathrm{SO}_{2}$ total release ranged from 0.4 to $1.9 \mathrm{~kg} \mathrm{~s}^{-1}$ during the observation period, a somewhat lower figure than the volcano's longer term time-averaged $\mathrm{SO}_{2}$ flux emissions of $3 \mathrm{~kg} \mathrm{~s}^{-1}$ (Allard et al., 2008). This reduced $\mathrm{SO}_{2}$ degassing in mid-July 2010 is in accord with the low to moderate level of volcanic activity and seismicity after the 25-30 June, 2010 major explosions (Aiuppa et al., 2011). In addition, our cameraderived time-averaged $\mathrm{SO}_{2}$ fluxes (Table 1 ) are consistent with results simultaneously obtained by the permanent network of UV scanning spectrometers operated by INGV-Catania (for the $3 \mathrm{~h}$ measurement shown in Fig. 4, we obtained a mean $\mathrm{SO}_{2}$ flux of $0.8 \pm 0.2 \mathrm{~kg} \mathrm{~s}^{-1}$, which corresponds well with the $\sim 0.9 \mathrm{~kg} \mathrm{~s}^{-1}$ daily average obtained on the same day by the scanning network).

The results shown in Fig. 4 also demonstrate that, when observed at a $\sim 1 \mathrm{~Hz}, \mathrm{SO}_{2}$ flux time series have a dynamic and complex structure which is un-resolvable by conventional UV scanning techniques. We identify two novel features in our dataset: (i) impulsive and large (up to $\sim 1.5 \mathrm{~kg} \mathrm{~s}^{-1}$ ) $\mathrm{SO}_{2}$ flux variations (Fig. 4a), and (ii) longer and milder (duration of hundreds of seconds; amplitude, $0.1-0.3 \mathrm{~kg} \mathrm{~s}^{-1}$ ) cyclic fluctuations in emission (Fig. 4b). We therefore conclude that the $\mathrm{SO}_{2}$ output from Stromboli systematically varies over timescales of seconds/minutes, with both impulsive and semi-cyclic behaviour.

The impulsive $\mathrm{SO}_{2}$ flux signals (duration, 15-30 s) are clearly the result of explosive gas release during individual Strombolian outbursts (Figs. 4 and 5). Each explosion is captured by our UV images (see sequence of frames (a) to (e) in Fig. 5, and video V1 in the auxiliary materials) as a fast-rising $\mathrm{SO}_{2}$ cloud, whose initial release time is nearly simultaneous with the thermal signal onset (as captured by radiometers) radiated by hot pyroclastic materials upon their ejection from the eruptive vent(s) (Fig. 5f).

Supplementary material related to this article can be found online at http://dx.doi.org/10.1016/j.epsl.2012.09.050.

Our results also show that each explosion is systematically followed by a long coda (up to $\sim 140 \mathrm{~s}$, Fig. $5 f$ ), during which the $\mathrm{SO}_{2}$ flux exponentially decreases to the pre-explosion value. This, combined with the intrinsically rhythmic nature of Strombolian explosions, gives rise to a manifestly periodic $\mathrm{SO}_{2}$ outgassing behaviour (Fig. 4b), with cycles of $\mathrm{SO}_{2}$ flux increasing and decreasing over typical timescales of 300-700 s. 


\section{2. $\mathrm{SO}_{2}$ release during Strombolian explosions}

The $\mathrm{SO}_{2}$ signal related to Strombolian explosions is clearly visible in our $\mathrm{SO}_{2}$ flux record (Fig. 4). In principle, integration of the area below the "explosive" $\mathrm{SO}_{2}$ flux curve (marked red in Fig. 5f) might straightforwardly be used to calculate the $\mathrm{SO}_{2}$ mass released during individual explosions. This operation is however complicated by two classes of problems: (a) our $\mathrm{SO}_{2}$ flux measurements are taken, looking only a few metres above the vent, where the effect of ash on the measured signal (see Fig. 3) is likely significant (at least for the ash-rich explosions); (b) the gas thrust at the base of the eruptive column is of high and rapidly-changing ascent speed (see below), implicitly reducing the accuracy in $\mathrm{SO}_{2}$ flux measurements.

We therefore used the two dimension integration technique (Section 2.3) to obtain more reliable estimates. Fig. 5 shows an example of this approach: for sets of consecutive images, we performed pixel-to-pixel two-dimensional integration of $\mathrm{SO}_{2}$ concentrations within the dotted area above the vents (Fig. 5a-e), and obtained the temporal variation of total $\mathrm{SO}_{2}$ mass (in $\mathrm{kg}$ ) in that area (given by the blue curve in Fig. 5f). This showed a smooth, systematically increasing then decreasing cycle after each explosion, the peak in $\mathrm{SO}_{2}$ mass being typically reached $74 \pm 38 \mathrm{~s}$ after the blast. By subtracting the $\mathrm{SO}_{2}$ contribution observed prior to and following the explosion (see dotted line below the blue curve in Fig. 5f) from the corresponding observed maximum value (Fig. $5 \mathrm{~d}$ ), we obtained the total $\mathrm{SO}_{2}$ mass released during each strombolian explosion. This background subtraction procedure was not required on days with stronger wind, where the passive and explosive plumes were clearly spatially segregated. Most of the explosions we measured were ash-free, leading to low overall error $( \pm 15 \%)$ in the mass measurements; only the NE crater produced explosions with ash, requiring use of the procedure detailed earlier (Section 2.3). By inspecting the camera image sequences, the explosions were evident as clouds of highly concentrated $\mathrm{SO}_{2}$ rising rapidly upwards (Fig. 5 and video V1 in the auxiliary materials). The initial velocity of the gas explosion peaked at $\sim 23 \mathrm{~m} \mathrm{~s}^{-1}$, slightly slower than but still in general agreement with previous measurements (Chouet et al., 1974; Ripepe and
Braun, 1994; Seyfried and Hort, 1999; Patrick et al., 2007). The gas jet initially rose very rapidly for the first $4-5 \mathrm{~s}$ (Ripepe et al., 2008), reaching heights of $40-140 \mathrm{~m}$, then decelerated to a constant velocity as the motion became convective.

During our campaign, we observed 133 discrete explosions overall, 29 from the NE crater and 118 from the SW crater (the latter were all ash-free). Explosions varied widely in style and appearance, but can be broadly categorized based on their rising gas speed and the geometry and evolution of the plume front. Following Patrick et al. (2007), we recognize two main groups: Type 1 (ballistic-dominated) and Type 2 (ash-dominated). Both types can be subdivided into two subgroups (Patrick et al., 2007), which either exhibit a visible gas thrust phase (a) or only convective velocities (b). Most of the observed explosions belonged to $1 \mathrm{a}$ and $1 \mathrm{~b}$ Types, respectively $43 \%$ and $41 \%$, whilst Type $2 \mathrm{a}$ and $2 \mathrm{~b}$ subgroups accounted for $19 \%$ and $5 \%$, respectively.

We found that the erupted $\mathrm{SO}_{2}$ mass per explosion ranged between 2 and $55 \mathrm{~kg}$, with an average of $\sim 20 \mathrm{~kg}$ for the 10th to 15th July 2010 period. The mean explosive frequency was $9.4 \pm 1.8$ events per hour during our observations, somewhat lower than (but still comparable with) the time averaged explosive rate of 13 events per hour for Stromboli (Delle Donne et al., 2006). From this, we estimate that the daily explosive $\mathrm{SO}_{2}$ mass output rate was $0.05 \pm 0.01 \mathrm{~kg} \mathrm{~s}^{-1}$. We therefore conclude that, on Stromboli, the explosive $\mathrm{SO}_{2}$ gas output accounts for $7 \pm 1.5 \%$ of the total $\mathrm{SO}_{2}$ flux of $\sim 0.7 \mathrm{~kg} \mathrm{~s}^{-1}$ (average of 10th-15th July total $\mathrm{SO}_{2}$ flux observations; see Table 1 ).

\section{3. $\mathrm{SO}_{2}$ release from puffing}

Gas puffs are rapid and repeated emissions of discrete packets of high-temperature gas from the vents (Harris and Ripepe, 2007). At Stromboli, puffing activity is mainly centred on only one vent at any given time (most often in the central craters' terrace area), although switching from one vent to another is often observed (Ripepe and Marchetti, 2002; Ripepe et al., 2007). A single puff usually forms a convecting cloud of gas that ascends from the vent. After a few tens of metres, the puff cools, decelerates, expands and begins to mingle within the surrounding plume,
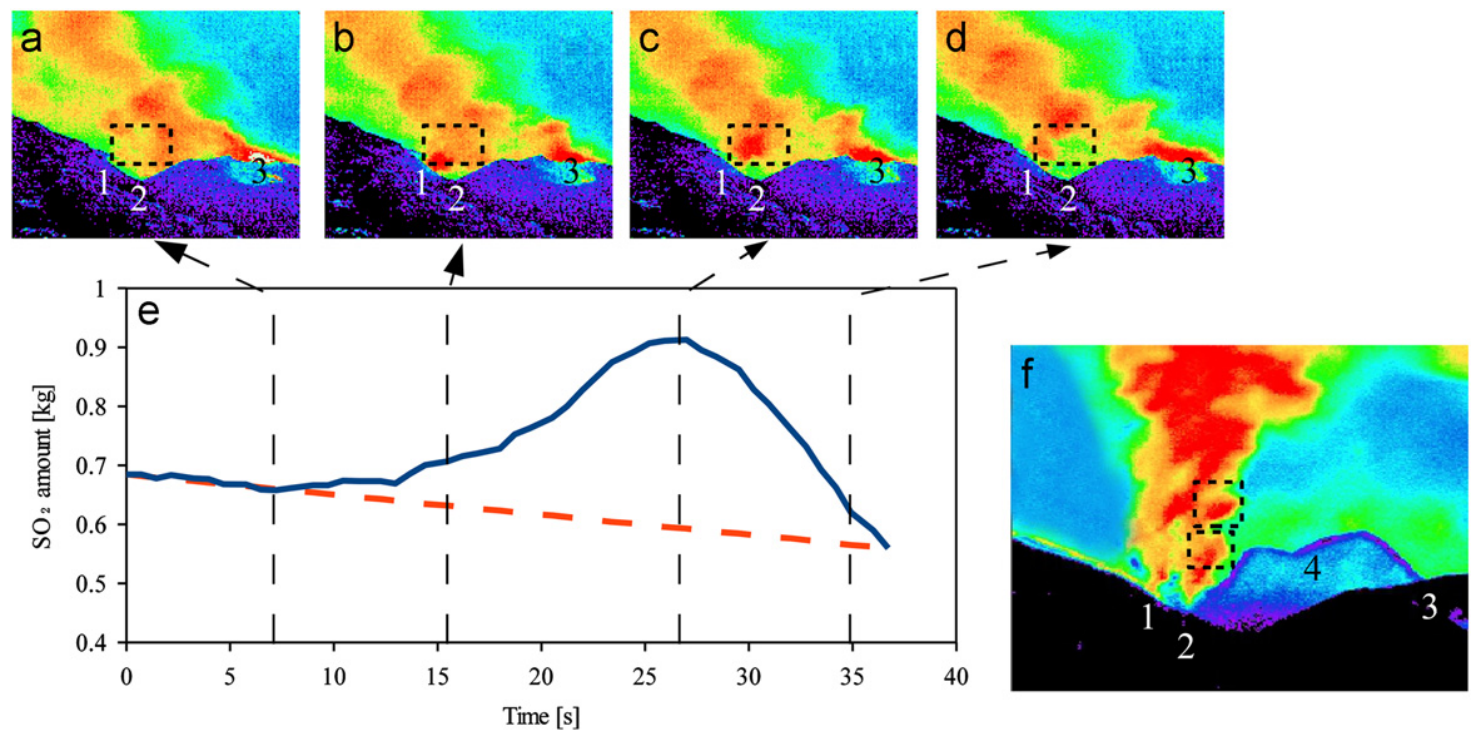

Fig. 6. (a-d) $\mathrm{SO}_{2}$ column amount image sequence of puffing from the central crater, observed on July 16 th 2010 . The corresponding time variation of the integrated $\mathrm{SO}_{2}$ amount, calculated by applying the two dimension integration technique (Section 2.3) to the area delimited by the dashed black box, is given in (e). The total $\mathrm{SO}_{2}$ mass released by the puff is calculated by subtracting the background (orange dashed line) from the maximum value of the $\mathrm{SO}_{2}$ amount curve (blue line). (f) A sequence of two puffs observed on May 20th 2011, clearly distinguishable from the adjacent plumes issuing from the SW crater (on the left in the image). Craters and their respective plumes are clearly visible: south-west (1), central (2), north-east (3) and a hornito (4, present since November 2010). 
issuing from the adjacent (quiescent or erupting) vents; therefore its individual character is lost rapidly (Harris and Ripepe, 2007).

In order to measure the $\mathrm{SO}_{2}$ content of puffs produced by the central crater, we performed two campaigns: on 16 July, 2010 and 21 May, 2011 and placed the dual-camera UV imaging system on the Roccette (ROC; Fig. 1) site, about $\sim 750 \mathrm{~m}$ asl and at a horizontal distance from the crater terrace of $\sim 450 \mathrm{~m}$.

During the first campaign, the infrasonic network of the Università di Firenze recorded very small pressure $(<2 \mathrm{~Pa})$ transients, indicating that puffing activity was rather weak. Detection of gas puffs by UV imaging was challenging, therefore, and only 11 relatively large puffs were identified and measured within an hour, whilst resolution of the majority of the (far smaller) puffs was not possible. Fig. 6a-d show a sequence of UV images, for one of the larger gas puffs entering the integration box (red dashed area) in (b), covering the largest part of the box in (c), and then disappearing to become diluted in the main plume (d). The resulting time variation of the cumulative $\mathrm{SO}_{2}$ mass in the box is given in (e), the maximum value in (c) (after subtraction of the baseline; red line in (e)) yield $\mathrm{SO}_{2}$ mass for an individual puff. The derived $\mathrm{SO}_{2}$ masses for single puffs ranged $0.14-0.45 \mathrm{~kg}$, averaging at $0.28 \mathrm{~kg}$. However, as only the largest puffs were measured, this average puff mass will represent an upper estimate in this case. Furthermore, infrasonic measurements indicate that the mean puffing rate at Stromboli ranges between 1 and 2 puffs per second (Ripepe et al., 1996; Ripepe et al., 2007), such that our sampling rate of $1.2 \mathrm{~Hz}$ $(\sim 0.8 \mathrm{~s})$ is close to the threshold required to resolve this rapid phenomenon. Notwithstanding these limitations, our $\mathrm{SO}_{2}$ puff mass, in concert with a puffing frequency of $\sim 0.6 \mathrm{~Hz}$ (obtained from our infrasonic recordings), can be used to estimate a daily mean flux of $0.16 \mathrm{~kg} \mathrm{~s}^{-1}$ (range between 0.08 and $0.26 \mathrm{~kg} \mathrm{~s}^{-1}$ ), which would represent $\sim 23 \%$ (from $11 \%$ up to $37 \%$ ) of the total volcanic $\mathrm{SO}_{2}$ flux budget $\left(0.7 \mathrm{~kg} \mathrm{~s}^{-1}\right)$.

During the 20th May 2011 campaign, more sustained ( $\gg 2 \mathrm{~Pa}$ ) puffing activity was observed on the volcano by the infrasonic network, and $\sim 50 \mathrm{SO}_{2}$ puffs were measured in just under one hour of observations. Fig. 6a-d shows a sequence of two gas puffs (dotted boxes) issuing from the central crater. The figure shows that, in spite of our sampling frequency of $1.2 \mathrm{~Hz}$ being close to the puffing frequency, we were still able to follow each puff, from emission at the vent up to heights of 10-30 $\mathrm{m}$ above the craters, but only when turbulent effects were at a minimum and the plume rose vertically with a buoyant ascent. In

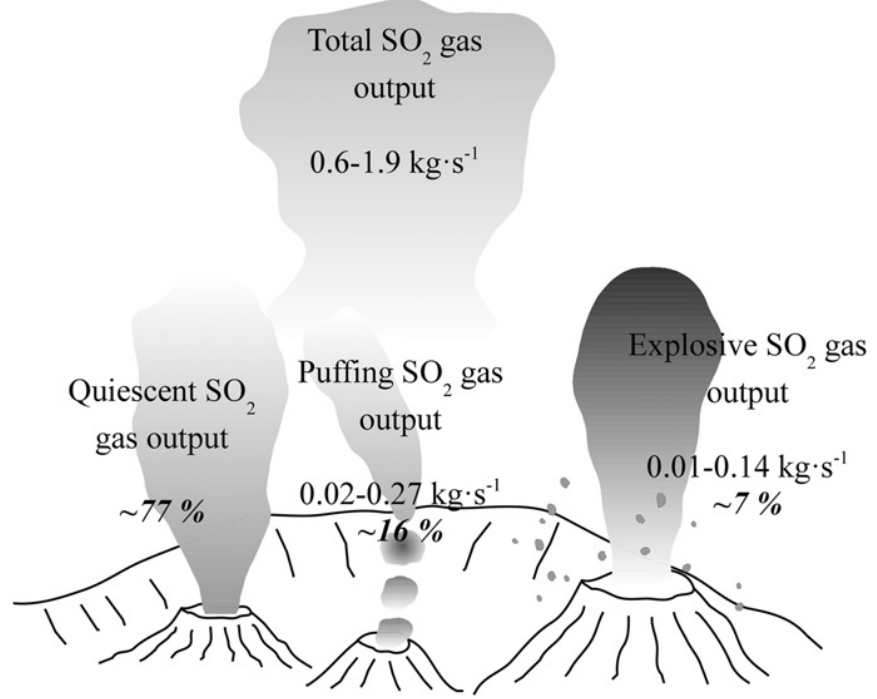

Fig. 7. Sketch diagram summarising the relative contribution of passive and active degassing (puffing and Strombolian explosions) to the total $\mathrm{SO}_{2}$ budget (see text). comparison, with thermal imagery, the puffs would no longer be distinguishable after $\sim 15 \mathrm{~m}$, when they have cooled to background plume temperature. The so-measured single-puff $\mathrm{SO}_{2}$ mass (20th May 2011 campaign) ranged $0.03-0.22 \mathrm{~kg}$, averaging $0.09 \mathrm{~kg}$ (or a factor $\sim 3$ less than measured in July 2010). For a mean puffing rate of $1.7 \mathrm{~s}$, this would correspond to a daily puffing $\mathrm{SO}_{2}$ flux of $\sim 0.05 \mathrm{~kg} \mathrm{~s}^{-1}$. Considering a total $\mathrm{SO}_{2}$ flux on 20th May 2011 of $1.7 \mathrm{~kg} \mathrm{~s}^{-1}$ this intimates a relatively marginal $(\sim 3 \%)$ contribution from puffing to the total degassing activity, which increases to $7 \%$ when compared to the mean total flux of $0.7 \mathrm{~kg} \mathrm{~s}^{-1}$.

\section{Discussion}

The results presented here clearly demonstrate the potential of the UV camera in characterizing - in near real-time - the different forms of gas release from an active volcano. Our observations, summarized in Fig. 7, clearly corroborate the earlier hypothesis (Allard et al., 1994, 2008) that a dominant role is played by quiescent degassing at Stromboli with active degassing contributing to $23 \%$ (ranging from $10 \%$ to $45 \%$ ) of the total $\mathrm{SO}_{2}$ budget (see below). Our observations furthermore demonstrate that strombolian explosions modulate (or are modulated by) cyclic volcanic degassing behaviour over timescales (minutes) much longer that the explosion duration (Fig. 4). This result provides direct evidence that the cyclic behaviour of explosive degassing, revealed by thermal (Ripepe et al., 2005) and infrasonic (Ripepe et al., 2002) measurements, is a real feature of degassing dynamics of this volcano.

The role of puffing in the degassing dynamics at Stromboli has been previously investigated only by indirect analysis of thermal image (Harris and Ripepe, 2007) and infrasonic data (Ripepe and Gordeev, 1999). Here we provide the first direct gas measurement based constraints on the total $\mathrm{SO}_{2}$ mass and flux rate from puffing. Our UV measurements clearly suggest that this previously overlooked degassing mechanism plays a major role in the explosive degassing dynamics of the magmatic system at Stromboli, releasing twice as much $\mathrm{SO}_{2}$ than strombolian explosions. Our measurements also open the way to in-depth exploration of significant aspects of magmatic degassing at Stromboli, as discussed below.

\subsection{Insights into explosive degassing}

Our observations contribute to extending the currently limited dataset for explosive $\mathrm{SO}_{2}$ emissions at Stromboli. Overall, our $\mathrm{SO}_{2}$ mass estimates $(2-55 \mathrm{~kg}$, mean $\sim 20 \mathrm{~kg}$ ) for 133 individual Strombolian events are in fair agreement with previous UV remotely sensed evaluations, yet based on more limited observation of only 5 (Mori and Burton, 2009) and 16 (McGonigle et al., 2009) explosions. Accepting the assertion of Burton et al. (2007a) that $\mathrm{SO}_{2}$ represents $\sim 4.2 \mathrm{wt} \%$ of the syn-explosive Strombolian gas phase, we calculate the total gas mass released during explosions to range $50-1310 \mathrm{~kg}$. At ambient conditions of $1 \mathrm{bar}$ and $298^{\circ} \mathrm{K}$, this corresponds to eruptive gas volumes of 44-1207 $\mathrm{m}^{3}$ (mean, $\sim 400 \mathrm{~m}^{3}$ ). Comparing this new estimate with previous volume evaluations, based on a variety of geophysical techniques, including infrasonic (Vergniolle and Brandeis, 1996; Ripepe and Marchetti, 2002) and seismic (Chouet et al., 2003), we conclude that the gas measurement based studies (including this one) all point to rather larger volumes $\left(\sim 400 \mathrm{~m}^{3}\right)$ than indicated by the less direct geophysical approaches $\left(\sim 100 \mathrm{~m}^{3}\right)$. This mismatch is explicable, however on the basis that geophysical-based volumes are relative to pressure and temperature conditions inside the conduit prior to bursting, 


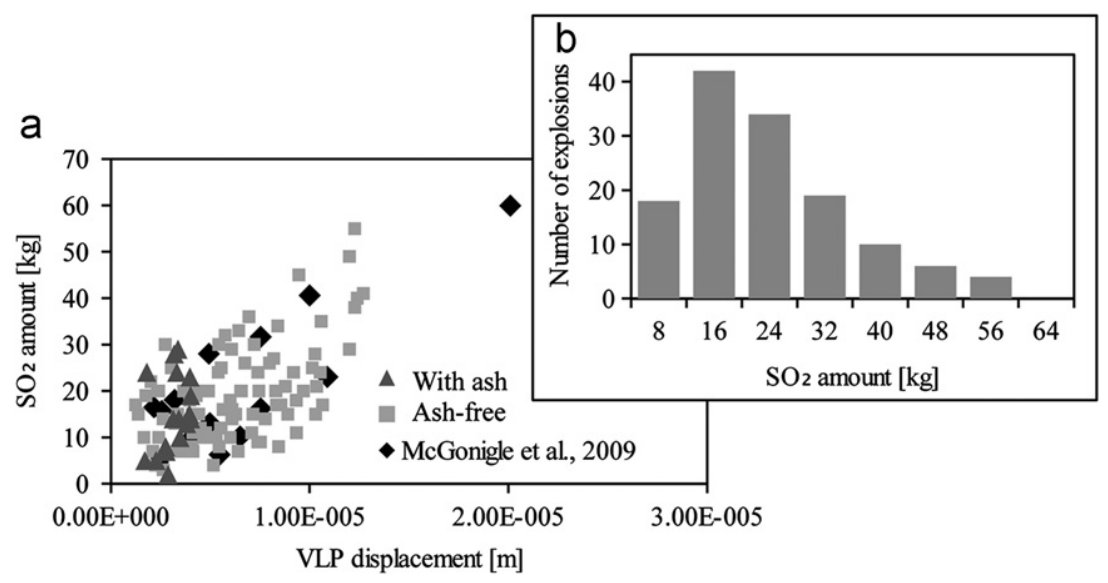

Fig. 8. (a) Scatter diagram of VLP displacement for individual strombolian explosions, plotted versus the corresponding syn-explosive $\mathrm{SO}_{2}$ mass and (b) a frequency histogram of the $\mathrm{SO}_{2}$ mass released during individual strombolian explosions,

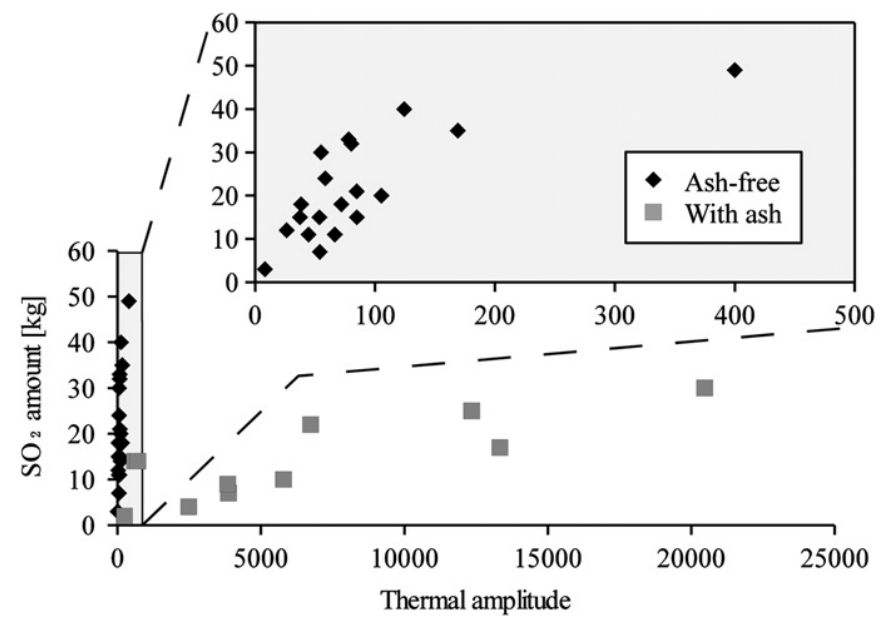

Fig. 9. Scatter diagram of thermal amplitude for individual strombolian explosions, plotted against the corresponding syn-explosive $\mathrm{SO}_{2}$ mass. The enlarged gray-filled graph zooms in on the ash-free explosions.

rather than volumes of surface-released gas (as captured during the gas measurements). Indeed, agreement between the two independent approaches is obtained if our UV camera estimated volumes are scaled to magmatic temperatures and pressures of $1340{ }^{\circ} \mathrm{K}$ and $90 \mathrm{bar}$, with the latter corresponding to magmastatic pressure at $\sim 300 \mathrm{~m}$ depth in the conduit, around the source depth of the VLP seismic signals (Chouet et al., 2003).

Our UV camera-based data enable computation of a mean daily explosive $\mathrm{SO}_{2}$ mass output rate of $0.05 \mathrm{~kg} \mathrm{~s}^{-1}$ (Fig. 7), e.g., only a small $(7 \pm 1.5 \%)$ fraction of the total emitted $\mathrm{SO}_{2}$ flux $\left(\sim 0.7 \mathrm{~kg} \mathrm{~s}^{-1}\right)$. However, explosions are also shown to play a key role in determining patterns of total gas release from the volcano (Fig. 4). We show, in fact, that the periodic $\mathrm{SO}_{2}$ outgassing behaviour of Stromboli (which we have here identified for the first time; Fig. 4) is modulated by, and therefore an ultimate effect of, the intrinsically rhythmic nature of Strombolian explosions. The large syn-explosive $\mathrm{SO}_{2}$ flux variation observed during each blast, and the ensuing few minutes-long coda of decreasing $\mathrm{SO}_{2}$ flux after the explosion (Fig. 5f), when regularly repeated over time, lead to cyclic $\mathrm{SO}_{2}$ flux variations, typically lasting 300-700 s (Fig. 4b). We conclude, therefore, that while explosions are relatively marginal gas contributors to the long-term $\mathrm{SO}_{2}$ budget, they do still tangibly affect the volcano's outgassing behaviour over timescales (minutes) much longer that the explosion duration itself (seconds).

Our UV camera observations also enable more in-depth exploration of the dynamics of gas release during strombolian explosions. This is achieved here by integrating our UV camerabased $\mathrm{SO}_{2}$ gas signals with simultaneous seismic and thermal observations from the multi-parametric geophysical network operated by the Università di Firenze (Ripepe et al., 2009) (Figs. 5, 8 and 9). This follows on from an earlier, far more limited, data corroboration of this nature by McGonigle et al. (2009), and aims to derive constraints on the source processes determining the large range $\left(2-55 \mathrm{~kg}\right.$ ) of observed explosive $\mathrm{SO}_{2}$ masses.

Fig. $5 \mathrm{f}$ shows this gas-geophysical comparison for the explosive event imaged by the sequence of frames in Fig. 5a-e. The figure shows that the explosion onset - taken as the onset of the thermal signal captured by the radiometer - corresponds well to the first UV image in which the explosion is clearly visible (frame b in Fig. 5). This suggests no substantial delay between emission of gas ( $\mathrm{SO}_{2}$ signal) and the cloud of ash and hot pyroclasts (which is the source for the majority of the irradiated thermal signal) (Ripepe et al., 2002; 2005; Delle Donne and Ripepe, 2012) during the strombolian explosions, or that the delay is shorter than the UV cameras' temporal resolution (1.2 s).

In addition, we observe a positive correlation between our syn-explosive $\mathrm{SO}_{2}$ masses and the corresponding peak-to-peak maximum VLP displacements (Fig. 8), which corroborates the previous result of McGonigle et al. (2009). A similar relationship has more recently been shown to exist at Asama volcano, where the volume of individual gas bursts scales with VLP moment release (Kazahaya et al., 2011). Syn-explosive $\mathrm{SO}_{2}$ masses also correlate well with the amplitude of the radiometer thermal signal (Fig. 9), following two distinct linear trends for the ashfree and the ash-rich explosions, respectively (Fig. 9). Thermal signals represent the total irradiance within the FOV from hot materials released during explosions, including ash, bombs, and lapilli. A volcanic cloud of ash, bombs and lapilli has high emissivity (with the contribution of each component to the total irradiance depending upon its specific emissivity and emitting surface area), and spreads over a wider surface area of the radiometer's field of view. In contrast, ash-free gas clouds, have very low IR emissivity while being the source of our UV camera signal. It is then quite surprising the strong correlation between $\mathrm{SO}_{2}$ mass measured by UV camera and the thermal radiance, essentially derived from the lithic portion of the volcanic explosion, intimates that the gas/mass ratio is fairly constant, at least 
for a single vent. The two different trends, for ash-free (SW crater) and ash-rich (NE crater) explosions (Fig. 9), can be explained as the consequence of different gas/ash-particles ratios, or as the effect of different areas covered by the explosive clouds within the thermal camera FOV (due to the different distance of the SW and NE craters from the camera).

However, ash-free and ash-rich explosions also appear to have different gas mass versus VLP amplitude relationships (Fig. 8), the former being typically characterised by less variable, and generally lower, $\mathrm{SO}_{2}$ masses $(<30 \mathrm{~kg})$ and VLP amplitudes $\left(<4 \times 10^{-6} \mathrm{~m}\right)$. This distinction is also not surprising and in line with the characteristics of VLP seismicity on Stromboli. The VLP seismic signals have characteristic waveforms for each of the different craters (Chouet et al., 2003) and/or different explosive dynamics (Ripepe et al., 2005). Our UV camera-based $\mathrm{SO}_{2}$ measurements provides strong evidence that VLP seismic dynamics are mainly controlled by the gas mass and the gas-to-solid ratio.

To conclude, the data shown in Figs. 5, 8 and 9 convey the straightforward (but hitherto only hypothetical) message that the larger the volume of gas coalescing and ascending within the conduit, the larger the resultant volumetric change in the conduit will be (e.g., higher VLP signal), the bigger the volume of gas bursting emitted during the explosions (higher $\mathrm{SO}_{2}$ ), as well as the amount of fragmented magma entrained into the eruption column (higher thermal) (Ripepe et al., 2005; Ripepe et al., 2008).

\subsection{Insights into gas puffing}

Gas puffing activity at Stromboli has been characterised over the last two decades by combined analysis of infrasonic transients and thermal imagery (Ripepe and Gordeev, 1999; Harris and Ripepe, 2007). Based on outcomes of geophysical model calculations predicated upon results of the above acoustic and thermal studies, it was concluded that puffing activity may account for a substantial fraction ( $\sim 45 \%)$ of Stromboli's total gas flux (Harris and Ripepe, 2007; Ripepe et al., 2008). However, no direct gas flux data have previously been reported in support of or contrary to this hypothesis. Here, we have presented the first direct $\mathrm{SO}_{2}$ mass measurements of individual gas puffs, showing that these are spread over quite a large range, from as low as $0.03 \mathrm{~kg}$ to as high as $0.45 \mathrm{~kg}$ (Section 2.6). Whilst we consider the range of puff masses (0.03-0.22 $\mathrm{kg}$ of $\mathrm{SO}_{2}$ ) from the May 2011 campaign to be more accurate than those from July 2010 (cfr. 3.3), we tentatively posit the entire $0.03-0.45 \mathrm{~kg}$ range, captured over both campaigns, as a preliminary estimate of the contribution of puffing to Stromboli's overall $\mathrm{SO}_{2}$ budget. Using these figures, and assuming that $\mathrm{SO}_{2}$ makes up $4.8 \mathrm{wt} \%$ of each puff (as quoted by Burton et al., 2007a for Stromboli's quiescent plume), we calculate the total gas mass emitted by each gas puff to fall in the $0.6-9 \mathrm{~kg}$ range. Our estimated average puff gas mass of $\sim 5 \mathrm{~kg}$ is half of the average value of $\sim 10 \mathrm{~kg}$ estimated from thermal image analysis, which assumed no air entrainment and was therefore considered by earlier authors (Harris and Ripepe, 2007) as an upper limit. For a gas puff density of $\sim 0.43 \mathrm{~kg} \mathrm{~m}^{-3}$ calculated at $625^{\circ} \mathrm{K}$ and $1.22 \cdot 10^{5} \mathrm{~Pa}$ - Harris and Ripepe (2007) - and of the chemical composition detailed in the Burton et al. (2007a) e.g., a molecular weight of $22.6 \mathrm{~g} \mathrm{~mol}^{-1}$, our $0.6-9 \mathrm{~kg}$ mass range would correspond to an estimated individual puff volume of $1.4-21.5 \mathrm{~m}^{3}$. Such volumes are one order of magnitude smaller than, and only partially overlap with,the range of puff volumes (19$211 \mathrm{~m}^{3}$, mean $48 \mathrm{~m}^{3}$ ) previously estimated by analysis of thermal imagery (Harris and Ripepe, 2007). We therefore conclude from our data that puffing contributes to the volcano's gas budget more marginally than previously thought. Using our $0.03-0.45 \mathrm{~kg}$ (average of $0.19 \mathrm{~kg}$ ) puffing $\mathrm{SO}_{2}$ mass range, with a puffing rate of $0.6 \mathrm{~Hz}$ and a total mean $\mathrm{SO}_{2}$ flux of $0.7 \mathrm{~kg} \mathrm{~s}^{-1}$, we estimate that puffing contributes $3-38 \%$ (mean of $16 \%$ ) of the total $\mathrm{SO}_{2}$ release (Fig. 7). This calculation is highly dependent on the applied puffing rate of $0.6 \mathrm{~Hz}$ : if more characteristic puffing rates were used (puffs are typically released every 0.8 and $1.2 \mathrm{~s}$ at Stromboli), we would then obtain somewhat larger puffing contributions (means of $34 \%$ and $23 \%$, respectively). In any case, our direct gas measurements confirm that puffing is the main source of the explosive degassing at Stromboli, which in total (puffing + explosions) contribute up to $\sim 23 \%$ of the total gas budget.

Ripepe and Gordeev (1999) proposed that puffing at Stromboli is associated with surface bursting of decimetre-sized gas bubbles ( $\sim 0.5 \mathrm{~m}$ radius), produced by coalescence (in the shallow conduit) of clouds of smaller layered bubbles (Manga, 1996). The coalescence of gas bubbles at Stromboli is indeed supported by textural studies on scoria samples (Polacci et al., 2009; Colò et al., 2010), providing strong evidence that bubbles with radius $>0.4 \mathrm{~mm}$ coalescence, for pressures $<50 \mathrm{MPa}$, to form networks of continuously connected vesicles, through which gas may eventually percolate to sustain quiescent (passive) gas emissions (Burton et al., 2007b). Periodic collapse of percolation pathways, and/or additional coalesce events at the top of the magmatic column, may ultimately allow for development of over-pressured gas pockets, which burst, leading to repeated puffing activity. Assuming a gas overpressure inside the bubble immediately before bursting of $2.2 \times 10^{4} \mathrm{~Pa}$ (Ripepe and Gordeev, 1999), and a gas temperature of $625^{\circ} \mathrm{K}$ (Harris and Ripepe, 2007), we infer, from our derived mass $(0.6-9 \mathrm{~kg})$ a gas bubble volume of $3.4 \mathrm{~m}^{3}$ for each gas puff which, for spherical bubble geometry, would lead to a bubble radius of $\sim 0.9 \mathrm{~m}$, close to the previous estimate $(0.5 \mathrm{~m})$ of Ripepe and Gordeev (1999). This match provides mutual confidence in both the geophysically based (Ripepe and Gordeev, 1999) and gas-based (this study) evaluations of this parameter.

\section{Conclusions}

Stromboli has been for decades an ideal laboratory for studying the different modes and rates of gas release from active volcanoes. Yet, a clear quantitative understanding of the relative contributions of passive and active degassing to the total gas budget has long remained unavailable.

Here, we have detailed results of a first field attempt to simultaneously assess $\mathrm{SO}_{2}$ release from the three main forms of degassing at Stromboli (Fig. 7). By exploiting the high spatial and temporal resolution of UV cameras, we have acquired image sequences for 133 Strombolian explosions, and estimated an $\mathrm{SO}_{2}$ mass output for individual eruptions of $2-55 \mathrm{~kg}$ (mean, $20 \mathrm{~kg}$ ), corresponding to a mean $\mathrm{SO}_{2}$ flux rate of $0.05 \mathrm{~kg} \mathrm{~s}^{-1}$. Considering that the total amount of $\mathrm{SO}_{2}$ measured during our experiment is $\sim 0.7 \mathrm{~kg} \mathrm{~s}^{-1}$, we corroborate previous indications that explosive activity contributes $7 \pm 1.5 \%$ of the total $\mathrm{SO}_{2}$ flux (Fig. 7). We have also reported on the first direct measurements of the $\mathrm{SO}_{2}$ mass contributed by puffing activity. Puffing has previously been a largely neglected secondary explosive process; yet, it occurs at Stromboli every $<2 \mathrm{~s}$, and has been inferred (via geophysics) to represent a rather persistent degassing mechanism, produced by bursting of small ( $<1 \mathrm{~m}$ radius) gas bubbles reaching the magma-air interface in over-pressurized conditions (Ripepe et al., 1996). Our UV measurements provide here the first quantitative evaluations of individual gas puffs $\mathrm{SO}_{2}$ masses $(\sim 0.19 \mathrm{Kg})$ and the related $\mathrm{SO}_{2}$ flux rate $\left(0.11 \mathrm{~kg} \mathrm{~s}^{-1}\right)$. These data clearly indicate that puffing is ultimately releasing more gas than explosive strombolian activity, accounting for at least $16 \%$ (at $1.7 \mathrm{~s}$ rate), - and perhaps as much as $38 \%$, of the total $\mathrm{SO}_{2}$ flux. 
We conclude from our measurements that, despite the coexistence of different modes of gas release, passive degassing remains the primary $(\sim 77 \%)$ mechanism of gas loss at Stromboli volcano, and probably at many other basaltic volcanoes. However, in spite of its relatively marginal contribution $(\sim 23 \%)$ to the overall gas budget, active degassing (explosions + puffing) plays a key role in modulating a cyclic (periods, 300-700 s) longer term $\mathrm{SO}_{2}$ degassing behaviour at Stromboli. This periodicity in gas emissivity may probably occur at other open-vent volcanoes world-wide, representing a key target to be explored by future research.

\section{Acknowledgements}

The authors wish to thank $\operatorname{Dr} C$. Werner for her very helpful reviews of this paper, Sergio Gurrieri of INGV-Palermo who has supported this work and Elizabeth Swanson and Accursio Tulone for their help during the field work. Kantzas E.P. acknowledges support of an AXA Post Doctoral Fellowship. The research leading to these results has received funding from the european research council under the European Union's Seventh Framework Programme (FP7/2007/2013)/ERC grant agreement $n^{\circ} 305377$.

\section{Appendix A. Supporting information}

Supplementary data associated with this article can be found in the online version at http://dx.doi.org/10.1016/j.epsl.2012.09.050. These data include Google map of the most important areas described in this article.

\section{References}

Allard, P., Carbonelle, J., Métrich, N., Loyer, H., Zettwoog, P., 1994. Sulphur output and magma degassing budget of Stromboli volcano. Nature 368, 326-330.

Allard, P., Burton, M., Murè, F., 2004. Spectroscopic evidence for a lava fountain driven by previously accumulated magmatic gas. Nature $433,407-410$, http:// dx.doi.org/10.1038/nature03246.

Allard, P., Aiuppa, A., Burton, M., Caltabiano, T., Federico, C., Salerno, G., La Spina, A., 2008. Crater gas emissions and the magma feeding system of Stromboli volcano. In: Calvari, S., Inguaggiato, S., Puglisi, G., Ripepe, M., Rosi, M. (Eds.), Learning from Stromboli: American Geophysical Union Geophysics Monograph Series, vol. 182; 2008, pp. 65-80.

Aiuppa, A., Burton, M., Allard, P., Caltabiano, T., Giudice, G., Gurrieri, S., Liuzzo, M., Salerno, G., 2011. First experimental evidence for the $\mathrm{CO}_{2}$-driven origin of Stromboli's major explosions. Solid Earh Discuss 3, 411-430, http://dx.doi.org/ 10.5194/sed-3-411-2011.

Andres, R.J., Kasgnoc, A.D., 1998. A time-averaged inventory of subaerial volcanic sulfur emissions. J. Geophys. Res. 103, 25251-25261.

Bluth, G.S.J., Shannon, J.M., Watson, I.M., Prata, A.J., Realmuto, V.J., 2007. Development of an ultra-violet digital camera for volcanic $\mathrm{SO}_{2}$ imaging. J. Volcanol. Geotherm. Res. 161, 47-56.

Boichu, M., Oppenheimer, C., Tsanev, V., Kyle, P.R., 2010. High temporal resolution $\mathrm{SO}_{2}$ flux measurements at Erebus volcano, Antarctica. J. Volcanol. Geotherm. Res. 190, 325-336.

Burton, M., Allard, P., Murè, F., La Spina, A., 2007a. Magmatic gas composition reveals the source depth of slug-driven Strombolian explosive activity. Science $317,227-230$.

Burton, M., Mader, H.M., Polacci, M., 2007b. The role of gas percolation in quiescent degassing of persistently active basaltic volcanoes. Earth Planet. Sci. Lett. 264, 46-60.

Chouet, B., Hamisevicz, B., McGetchin, T.R., 1974. Photoballistics of volcanic jet activity at Stromboli, Italy. J. Geophys. Res. 79, 4961-4976.

Chouet, B., Dawson, P., Ohmina ${ }_{t}$, T., Martini, M., Saccorotti, G., Giudicepietro, F., De Luca, G., Milana, G., Scarpa, R., 2003. Source mechanism of explosions at Stromboli Volcano, Italy, determined from moment-tensor inversions of verylong-period data. J. Geophys. Res. 108 (B1), 2019, http://dx.doi.org/10.1029/ 2002JB001919.

Colò, L., Ripepe, M., Baker, D.R., Polacci, M., 2010. Magma vesiculation and infrasonic activity at Stromboli open conduit volcano. Earth Planet. Sci. Lett. 292, 274-280, http://dx.doi.org/10.1016/j.epsl.2010.01.018.

Dalton, M., Watson, I., Nadeau, P., Werner, C., Morrow, W., Shannon, J., 2009. Assessment of the UV camera sulfur dioxide retrieval for point source plumes. J. Volcanol. Geotherm. Res. 188, 358-366.
Delle Donne, D., Marchetti, E., Ripepe, M., Ulivieri, G., Lacanna, G., 2006. Monitoring explosive volanic activity using thermal images, Stromboli volcano, Italy. Eos Trans. AGU 79, 1795.

Delle Donne, D., Ripepe, M., 2012. High-frame rate thermal imagery of Strombolian explosions: implications for explosive and infrasonic source dynamics. J. Geophys. Res. 117 (B09206), 12, http://dx.doi.org/10.1029/2011JB008987.

Harris, A., Ripepe, M., 2007. Temperature an dynamics of degassing at Stromboli. J. Geophys. Res., 112, http://dx.doi.org/10.1029/2006JB004393.

Holland, P.A.S., Watson, M.I., Phillips, J.C., Caricchi, L., Dalton, M.P., 2011. Degassing processes during lava dome growth: insights from Santiaguito lava dome, Guatemala. J. Volcanol. Geotherm. Res. 202, 153-166.

Kantzas, E.P., McGonigle, A.J.S., Tamburello, G., Aiuppa, A., Bryant, R.G. 2010. Protocols for UV camera volcanic $\mathrm{SO}_{2}$ mesurements. J. Volcanol. Geotherm. Res. 194, 55-60, http://dx.doi.org/10.1016/j.jvolgeores.2010.05.003.

Kazahaya, R., Mori, T., Takeo, M., Ohminato, T., Urabe, T., Maeda, Y., 2011. Relation between single very-long-period pulses and volcanic gas emissions at Mt Asama, Japan. Geophys. Res. Lett. 38, L11307, http://dx.doi.org/10.1029/2011GL047555.

Kern, C., Deutschmann, T., Vogel, L., Wöhrbach, M., Wagner, T., Platt, U., 2009. Radiative transfer corrections for accurate spectroscopic mesurements of volcanic gas emissions. Bull. Volcanol. , http://dx.doi.org/10.1007/s00445009-0313-7.

Manga, M., 1996. Waves of bubbles in basaltic magmas and lavas. J. Geophys. Res. $101,17457-17465$

McGonigle, A.J.S., Oppenheimer, C., 2003. Optical sensing of volcanic gas and aerosol emissions. In: Oppenheimer, C., Pyle, D.M., Barclay, J. (Eds.), Volcanic Degassing, vol. 213. Geological Society, London, Special Publications, pp. 149-168.

McGonigle, A.J.S., Aiuppa, A., Ripepe, M., Kantzas, E.P., Tamburello, G., 2009. Spectroscopic capture of $1 \mathrm{~Hz}$ volcanic $\mathrm{SO}_{2}$ fluxes and integration with volcano geophysical data. Geophys. Res. Lett. 36, L21309, http://dx.doi.org/10.1029/ 2009GL040494.

Mori, T., Burton, M., 2006. The $\mathrm{SO}_{2}$ camera: a simple, fast and cheap method for ground-based imaging of $\mathrm{SO}_{2}$ in volcanic plumes. Geophys. Res. Lett. 33, L24804, http://dx.doi.org/10.1029/2006GL027916.

Mori, T., Burton, M., 2009. Quantification of the gas mass emitted during single explosions on Stromboli with the $\mathrm{SO}_{2}$ imaging camera. J. Volcanol. Geotherm. Res. 188, 395-400, http://dx.doi.org/10.1016/j.jvolgeores.2009.10.005.

Nadeau, P.A., José, L.P., Waite, G.P., 2011. Linking volcanic tremor, degassing, and eruption dynamics via $\mathrm{SO}_{2}$ imaging. Geophys. Res. Lett. 38, L01304, http://dx.d oi.org/10.1029/2010GL045820.

Oppenheimer, C., 2003. Volcanic degassing. In: Holland, H., Turekian, K. (Eds.), The crust, Treatise on Geochemistry, vol. 3. Elsevier-Pergamon, Oxford, pp. 123166 (chapter 3.04)

Oppenheimer, C., Scaillet, B., Martin, R.S., 2011. Sulfur degassing from volcanoes: source conditions, surveillance, plume chemistry and earth system impacts. Reviews in Mineralogy \& Geochemistry. Miner. Soc. Am.

Parfitt, E.A., 2004. A discussion of the mechanisms of explosive basaltic eruptions. J. Volcanol. Geotherm. Res. 134, 77-107.

Patrick, M., Harris, A.J.L., Dehn, J., Ripepe, M., Rothery, D.A., Calvari, S., 2007. Strombolian explosive styles and source conditions: insights from thermal video (FLIR) imagery. Bull. Volcanol. 69, 769-784, http://dx.doi.org/10.1007/ s00445-006-0107-0.

Polacci, M., Baker, D.R., Mancini, L., Favretto, S., Jill, R.J., 2009. Vesiculation in magmas from Stromboli and implications for normal Strombolian activity and paroxysmal explosions in basaltic systems. J. Geophys. Res. 114, B01206, http:/ /dx.doi.org/10.1029/2008JB005672.

Ripepe, M., Poggi, P., Braun, T., Gordeev, E., 1996. Infrasonic waves and volcanic tremor at Stromboli. Geophys. Res. Lett. 23, 181-184.

Ripepe, M., Braun, T., 1994. Air-wave phases in strombolian explosion-quake seismograms: a possible indicator for magma level? Acta Vulcanol. 5, 201-206.

Ripepe, M., Gordeev, E., 1999. Gas bubble dynamics model for shallow volcanic tremor at Stromboli. J. Geophys. Res. 104 (B5), 10639-10654.

Ripepe, M., Harris, A.J.L., Carniel, R., 2002. Thermal, seismic and infrasonic evidences of variable degassing rates at Stromboli volcano. J. Volcanol. Geotherm. Res. 118, 285-297.

Ripepe, M., Marchetti, E., 2002. Array tracking of infrasonic sources at Stromboli volcano. Geophys. Res. Lett. 29 (22), 2076, http://dx.doi.org/10.1029/ 2002 GL015452.

Ripepe, M., Harris, A.J.L., Marchetti, E., 2005. Coupled thermal oscillations in explosive activity at different craters of Stromboli volcano Geophys. Res. Lett. 32, L17302, http://dx.doi.org/10.1029/2005GL022711.

Ripepe, M., Marchetti, E., Ulivieri, G., 2007. Infrasonic monitoring at Stromboli Volcano during the 2003 effusive eruption: Insights on the explosive and degassing process of an open conduit system. J. Geophys. Res. 112, B09207. http://dx.doi.org/10.1029/2006JB004613.

Ripepe, M., Delle Donne, D., Harris, A., Marchetti, E., Ulivieri, G., 2008. Dynamics of Stromboli activity. In: Calvari, S., Inguaggiato, S., Puglisi, G., Ripepe, M., Rosi, M. (Eds.), Learning from Stromboli: American Geophysical Union Geophysics Monograph Series, vol. 182; 2008, pp. 39-48.

Ripepe, M., Delle Donne, D., Lacanna, G., Marchetti, E., Ulivieri, G., 2009. The onset of the 2007 Stromboli effusive eruptions recorded by an integrated geophysical network. J. Volcanol. Geotherm. Res. 182, 131-136, http://dx.doi.org/ 10.1016/j.jvolgeores.2009.02.01

Seyfried, R., Hort, M., 1999. Continuous monitoring of volcanic eruption dynamics: a review of various techniques and new results from a frequency-modulated radar Doppler system. Bull. Volcanol. 60, 627-639. 
Shinohara, H., 2008. Excess degassing from volcanoes and its role on eruptive and intrusive activity. Rev. Geophys. 46, http://dx.doi.org/10.1029/2007RG000244 RG4005.

Tamburello, G., Kantzas, E.P., McGonigle, A.J.S., Aiuppa, A., 2011a. Recent advances in ground-based ultraviolet remote sensing of volcanic $\mathrm{SO}_{2}$ fluxes. Ann. Geophys. 54 (2), 199-208, http://dx.doi.org/10.4401/ag-5179.

Tamburello, G., Kantzas, E.P., McGonigle, A.J.S., Aiuppa, A., Giudice, G., 2011b. UV camera measurements of fumarole field degassing (La Fossa crater, Vulcano, Island). J. Volcanol. Geotherm. Res. 199, 47-52, http://dx.doi.org/10.1016/ j.jvolgeores.2010.10.004
Tamburello, G., Kantzas, E.P., McGonigle, A.J.S., Aiuppa, A., 2011c. Vulcamera: a program for measuring volcanic $\mathrm{SO}_{2}$ using UV cameras. Ann. Geophys. 54 (2), 219-221, http://dx.doi.org/10.4401/ag-518.

Vergniolle, S., Brandeis, G., 1996. Strombolian explosion: a large bubble breaking at the surface of a lava column as a source of sound. J. Geophys. Res. 101 (B09) 20433-20448.

Yamamoto, H., Watson, I.M., Phillips, J.C., Bluth, G.J., 2008. Rise dynamics and relative ash distribution in vulcanian eruption plumes at Santiaguito Volcano, Guatemala, revealed using an ultraviolet imaging camera. Geophys. Res. Lett. 35, L08314, http://dx.doi.org/10.1029/2007GL032008. 